\title{
Recurrent destructive grazing of successionally immature kelp forests by green sea urchins in Vestfjorden, Northern Norway
}

\author{
Nils T. Hagen \\ Department of Fisheries and Natural Science, Bodø College, N-8002 Bodø, Norway
}

\begin{abstract}
Outbreak populations of the green sea urchin Strongylocentrotus droebachiensis Müller caused widespread decimation of the original Laminaria hyperborea (Gunn.) Fosl. kelp forest in Vestfjorden, Northern Norway, during the early 1980s. In the following decade, some of the resulting urchin-dominated barren grounds reverted to kelp forest, which, after persisting for more than 5 yr, began to be eliminated yet again. Age analysis of annual growth rings in kelp stipes from field sites at Værøy Island indicate that the time of initial kelp recovery varied from site to site but took place between 1984 and 1987. The earliest independent observations of localized macrophyte recovery were made in 1984 at the Harbour Pier site, where, by August 1992, the new kelp forest had already been eliminated by recurrent destructive grazing. Sea urchin density inside re-established kelp forests at 3 other sites on Værøy Island was 45 to 75 ind. $\mathrm{m}^{-2}$ in 1992 . These urchin populations had significantly aggregated spatial patterns, and recurrent destructive grazing appeared to be imminent. This prediction was verified in 1993 when barren grounds reappeared at all study sites. The threshold conditions for initiation of destructive grazing have been approximated by a curve in the aggregation-density plane. Sea urchins in the Vestfjorden area are infected by the recently discovered epizootic endoparasitic nematode Echinomermella matsi. In 1992, the prevalence of E. matsiat Værøy Island ranged from $8.8 \%$ in the barren ground at the Harbour Pier site, to between 13.6 and $21.6 \%$ in the successionally immature kelp forest at the 3 other sites. The observed kelp forest recovery at Vaeroy Island was predicted by the macroparasite hypothesis which states that E. matsi may function as a terminator of sea urchin outbreaks in Northern Norway. However, the succession towards an ecologically mature kelp forest community has been interrupted by the unexpected recurrence of destructive grazing, and the macroparasite hypothesis must therefore be rejected in its present form. Furthermore, these local events may, on the larger time and spatial scales of the current outbreak phenomenon, indicate that the euphotic hard bottom component of the coastal ecosystem in Northern Norway has entered a cyclical domain.
\end{abstract}

KEY WORDS: Sea urchin outbreak - Kelp forest destruction - Epizootic disease Aggregation · Strongylocentrotus - Laminaria Echinomermella

\section{INTRODUCTION}

Sea urchins are important agents of disturbance and are frequently regarded as proximate determinants of community structure in subtidal marine macrophyte habitats (reviews by Lawrence 1975, Lawrence \& Sammarco 1982, Dayton 1985, Schiel \& Foster 1986, Harrold \& Pearse 1987, Chapman \& Johnson 1990). This generalization is based, in part, on evidence indicating that outbreak populations of sea urchins can decimate large kelp forests (Leighton et al. 1966, Leighton 1971, Breen \& Mann 1976, Foreman 1977. Hagen 1983) and maintain a barren community configuration dominated by crustose coralline algae (Chapman 1981); and, in part, on evidence indicating that reduced grazing pressure in such barren grounds invariably triggers rapid recolonization of kelp (Breen \& Mann 1976, Pearse \& Hines 1979, Duggins 1980, Andrew \& Choat 1982, Breen et al. 1982, Himmelman et al. 1983, Dayton et al. 1984, Miller 1985b, Novaczek \& McLachlan 1986, Scheibling 1986, Hughes et al. 1987, Keats et al. 1990). How- 
ever, at the next level of causality there exists a multitude of little known factors which, depending on the initial community configuration, may either control the onset of destructive grazing or allow a reduction in grazing pressure to a level which permits macroalgal recovery.

Currently, the 2 leading hypotheses of sea urchin outbreak termination state that the transition from urchin-dominated barren ground to kelp forest is facilitated by reintroduction of a keystone predator, or by epizootics of microparasitic (sensu Anderson \& May 1979) disease. The keystone predator hypothesis of outbreak termination pertains to only 1 species, the Pacific sea otter Enhydra lutris Milne-Edwards (Estes \& Palmisano 1974, Estes \& Harrold 1988, Foster \& Schiel 1988), while the hypothesis of microparasitic disease-related outbreak termination, although evoked in connection with several incidences of sea urchin mass mortality (Pearse et al. 1977, Boudouresque et al. 1980, Lessios et al. 1984, Dayton et al. 1992), has in only 1 instance been supported by conclusive identification of the suspect pathogenic agent, i.e. the amoeba Paramoeba invadens Jones (Jones 1985, Jones \& Scheibling 1985, Jones et al. 1985a, b). Other suggested mechanisms which may reduce the grazing pressure of sea urchins sufficiently to permit macroalgal recovery include a lack of recruitment of juvenile sea urchins (Foreman 1977, Watanabe \& Harrold 1991), storm disturbance (Harris et al. 1984, Ebeling et al. 1985, Andrew 1991), or a temporarily increased influx of unattached food items (Duggins 1981, Harrold \& Reed 1985),

Nevertheless, none of these suggested mechanisms of outbreak termination appear to be acting upon outbreak populations of the green sea urchin Strongylocentrotus droebachiensis Müller in Northern Norway (Hagen 1983, 1987). Instead a novel hypothesis of outbreak termination by macroparasitic (sensu May \& Anderson 1979) epizootic disease has been proposed (Hagen 1992). This hypothesis was inspired by the recent discovery of Echinomermella matsi (Jones \& Hagen 1987), a large endoparasitic nematode whose abundance has reached epizootic proportions in the Norwegian outbreak populations of $S$. droebachiensis (Hagen 1987). The macroparasite hypothesis predicts that parasite-induced mortality of adult sea urchins may reduce sea urchin density sufficiently to permit regrowth of kelp and other non-encrusting macroalgae, but, unlike the dramatic mass mortalities induced by epizootics of microparasitic disease agents (Pearse et al. 1977, Boudouresque et al. 1980, Lessios et al. 1984, Scheibling \& Stephenson 1984, Jones \& Scheibling 1985), it is expected that the potential regulatory impact of $E$. matsi is reflected by a gradual decline of a heavily parasitized urchin population.
This paper reports regrowth of kelp, as predicted by the macroparasite hypothesis, in an area of Northern Norway where the original kelp forest was destroyed by outbreak populations of Strongylocentrotus droebachiensis in the early 1980 s. The unexpected recurrence of destructive grazing in the successionally immature kelp forest is also reported, and the ecological implications of this novel phenomenon are discussed.

\section{MATERIALS AND METHODS}

Sampling. Samples of sea urchins and kelp were collected by SCUBA divers at 4 previously investigated field sites at Værøy Island on 25 to 27 August 1992 (Måstad, Lighthouse Bay, Tiny Bay, Harbour Pier). The location of the field sites is described in an earlier paper (Hagen 1987. Fig. 1B therein), which is also the source of the pre-1991 raw data figures used in the present study.

Sea urchins were collecting by repeated spot sampling of all specimens within reach of a stationary diver. At each field site the sampling spots were haphazardly chosen to randomize the collection, and at each sampling spot the substratum was thoroughly searched for small and cryptic individuals in an attempt to ensure that a representative sample was obtained. This method is considered adequate for sea urchins $\geq 5 \mathrm{~mm}$ in diameter but not for smaller individuals from the 0 age group cohort.

All collected sea urchins were temporarily stored in running seawater tanks onboard the research vessel of Nordland College, RV 'Raud'. The collected urchins from 2 sites (Måstad and Tiny Bay) were immediately processed in a field laboratory on Værøy Island, while the urchins from the 2 additional sites (Harbour Pier and Lighthouse Bay) were transported by RV 'Raud' to another running seawater facility at The Marine Laboratory of Nordland College and processed by 2 September 1992. The test diameter of the collected sea urchins was measured using vernier callipers with $0.1 \mathrm{~mm}$ precision. The kurtosis and skewness of the size-frequency distributions were tested for departure from a normal distribution as described by Sokal \& Rohlf (1981).

All collected sea urchins were dissected, and the perivisceral coelom of each sea urchin was inspected under a magnifying lamp to determine whether parasitic nematodes were present. The null hypothesis of no difference in parasite prevalence in the samples from 1983 and 1992 was tested in a 2-way contingency table analysis ( $G$-test; Sokal \& Rohlf 1981). Heterogeneity of variances (Bartlett's test; $\mathrm{p}<0.001$ ) and nonnormality (see Table 1) precluded the use of ANOVA in the analysis of sea urchin test diameter data. In an 
alternative approach the test diameters of infected and non-infected urchins in samples from 1983 and 1992 date were compared using Kolmogorov-Smirnov tests.

Sea urchin density was estimated by counting all urchins inside a $0.25 \mathrm{~m}^{2}$ frame. At each site at least 15 replicates were made between 1 and $10 \mathrm{~m}$ depth. The site-specific effect of sampling time on sea urchin density was analysed by fixed effect (cf. Bennington \& Thayne 1994), single factor ANOVA. A significant ANOVA with 2 degrees of freedom was followed by a Tukey-Kramer post hoc comparison of means. Prior to analysis homogeneity of variances was checked using Bartlett's test, and normality of the pooled residuals (Sokal \& Rohlf 1981) was checked by percentile plots (Sager et al. 1992). The density data were also used to assess the spatial aggregation of the sea urchin populations. A chi-squared test was used to check whether the variance/mean ratio of the sample differed from 1 (Elliott 1977, cf. Hurlbert 1990, p. 263), and the degree of aggregation was evaluated by estimating Morisita's index, $\hat{l}_{\mathrm{M}}$ (Morisita 1971, cf. Hurlbert 1990, p. 267).

At each field site samples of the kelp Laminaria hyperborea (Gunn.) Fosl. were collected by cutting the stipes of 17 to 20 adult kelp plants just above the holdfast. An approximately $5 \mathrm{~cm}$ long piece from the basal end of each stipe was preserved in formaldehyde diluted in seawater to $<10 \%$ concentration. To count the number of annual growth-rings (Kain 1963), cross sections from these pieces were examined in transmitted light under a dissecting microscope.

The qualitative community configuration, barren ground or kelp forest, was surveyed from the surface using a small boat equipped with a glass-bottom observation tube. The visible range through the observation tube was 10 to $15 \mathrm{~m}$ depth. At each field site continuous visual transects of approximately $1 \mathrm{~km}$ length were made, and the community configuration was subjectively assessed as a percentage of the surveyed area. These surface observations were made at the time of SCUBA observations in 1992 and again on 30 to 31 July 1993. Previous surface observations at the same sites were made in 1980, 1981, 1983 and 1984 (Hagen 1983, 1987).

Data were analyzed using SuperANOVA (Gagnon et al. 1989), StatView (Sager et al. 1992), and Microsoft Excel $^{\text {TM }}$ software.

\section{RESULTS}

\section{Macroalgae recovery}

By 1992, more than 10 yr after destruction of the original kelp forest (Hagen 1983), >90\% of the former urchin-dominated barren grounds at Værøy Island had reverted to dense macrophyte beds dominated by the perennial kelp Laminaria hyperborea. However, the kelp forest at the Harbour Pier site was confined to a small stand (<100 $\mathrm{m}$ across) of $L$. hyperborea, and there were a few isolated holes ( $<100 \mathrm{~m}$ across) in the kelp canopy outside Mt. Măstad (1 km south of the Måstad field site, cf. Hagen 1983, Fig. 1B therein). A small patch $(<100 \mathrm{~m}$ across) of the early successional brown alga Desmarestia aculeata (L.) Lamour. was still present in the kelp forest at the Tiny Bay site but had been replaced by a continuous canopy of kelp by July 1993.

SCUBA observations revealed that the stipes and holdfasts of the re-established kelp plants were conspicuously bare, compared with the lush epiphyte vegetation observed before the destruction of the original kelp beds (cf. Hagen 1983, Fig. 7 therein, Hagen 1987, Fig. 5 therein). The dominant epiphytes on the stipes and holdfasts of the new kelp plants were young coralline crusts (apparently Lithothamnion glaciale Kjellman) and a minute fuzz of the filamentous red alga Audouinella purpurea (Lightf.) Woelkerling.

Age determination of kelp plants suggests that the initial recruitment occurred in 1984 (Harbour Pier), 1985 (Lighthouse Bay), 1986 (Tiny Bay), and 1987 (Måstad) (Figs. 1 \& 2). The kelp-ageing method was verified by independent surface observations which indicate that the initial macrophyte recovery at Værøy Island occurred in 1984, in localized areas outside the Harbour Pier and in Lighthouse Bay (Hagen 1987). However, the 1 yr discrepancy between the ob-served and estimated time of kelp recruitment in Lighthouse Bay, as well as the presence of only a single plant from 1984 in the Harbour Pier sample (Fig. 1), suggests that the kelp-ageing method provides a conservative estimate of the time of the initial kelp reestablishment at each site. The low frequency of old plants in the kelp samples (Fig. 1) may also indicate that kelp recovery progressed gradually after the initial re-establishment.

\section{Recurrent destructive grazing}

In 1992, extensive urchin-dominated barren grounds were observed at the Harbour Pier site, and sea urchins were also abundant inside holes in the kelp canopy outside Mt. Måstad (surface observation; cf. Hagen 1983, Fig. 1B therein). Furthermore, SCUBA diving revealed dense populations of exposed sea urchins below the new kelp canopies at the remaining field sites (Mâstad, Lighthouse Bay, Tiny Bay, Fig. 3), not unlike the situation observed in 1980-1981 during the early stages of the outbreak (Hagen 1983). 


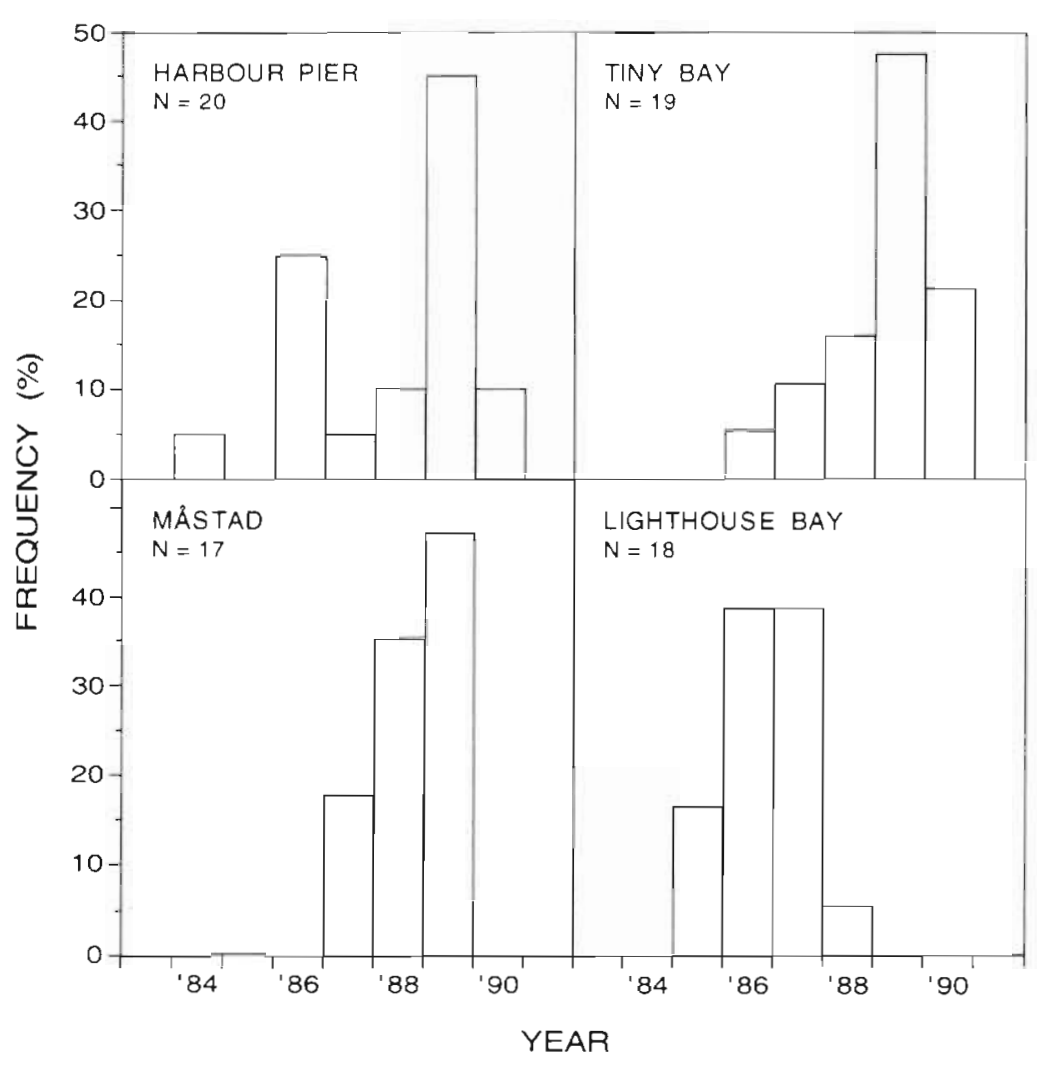

Fig. 1 Laminaria hyperborea. Age-frequency distribution of kelp plants in samples from Verøy Island, Northem Norway

By 1993 the sublittoral vegetation at Måstad had been transformed into a parklike mosaic of barren ground and kelp patches, where the remaining kelp patches covered $<50 \%$ of the bottom. Large barren patches (>100 $\mathrm{m}$ across) had also appeared in Lighthouse Bay, there were some smaller holes $(\approx 10 \%$ of the surveyed area) in the kelp canopy in Tiny Bay, and the barren-ground configuration at the Harbour Pier site appeared qualitatively unchanged. This pattern of decline of the re-established kelp forest at Værøy
Island parallels the pattern of decline during the destruction of the original kelp forest 12 yr earlier (Hagen 1983).

\section{Sea urchin density and aggregation}

The quantitative analysis suggest that sea urchin density in 1992 was similar (Tiny Bay, Harbour Pier) or higher (Måstad, Lighthouse Bay) than it was in 1983 (Tables 1 \& 2). However, in 1984 the urchin density in Lighthouse Bay, and outside the Harbour Pier, was subjectively estimated at $<1$ ind. $\mathrm{m}^{-2}$ (Hagen 1987). It would seem, therefore, that lack of quantitative sampling between 1983 and 1992 conceals large fiuctuations in sea urchin density which made macrophyte recovery possible (Fig. 1).

Estimates of aggregation and mean density were obtained from 3 kelp resident sea urchin populations at Værøy Island in 1992, at the time of the onset of destructive grazing (see 'Recurrent destructive grazing'). The resulting curve in the aggregation-density plane, which connects the 3 estimates, provides a tentative estimate of the threshold for onset of destructive grazing in a successional Laminaria hyperborea forest (Fig. 3). The curve indicates that a high degree of aggregation facilitates destructive grazing at intermediate sea urchin density. Conversely, high sea urchin density facilitates destructive grazing at low levels of aggregation. The data points from barren grounds are located below the curve, suggesting that aggregation levels decrease after the kelp forest has been eliminated by destructive grazing.

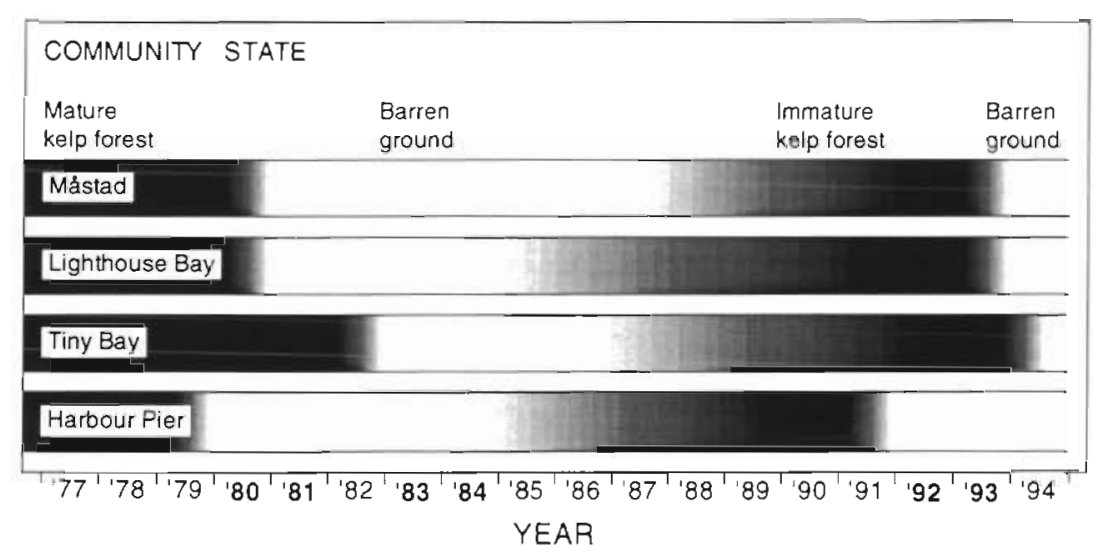

Fig. 2. Laminaria hyperborea and Strongylocentrotus droebachiensis. Community dynamics at 4 field sites on Værøy Island, Northern Norway. During the early 1980s, the mature L. hyperborea kelp forest was replaced by barren grounds dominated by the sea urchin $S$ droebachiensis. Kelp regrowth occurred in the mid 1980s, but this re-established kelp forest was destroyed and replaced by barren grounds again in the early 1990s when it was still successionally immature. Years when observations were made indicated with bold typeface. The time of kelp regrowth at Mastad and in Tiny Bay was estımated by ageing of kelp plants collected in 1992 
Table 1 Strongylocentrotus droebachiensis and Echinomermella matsi. Sampling data and population characteristics for sea urchins from Værøy Island, Northern Norway. SE in parentheses; $N$ : total number of collected specimens; $N_{0}$ : number of infected $S$. droebachiensis; $N_{r}$ : number of replicate density measurements; $t_{41}$ and $t_{\mathrm{s} 2}$ : $t$-values for skewness $\left(g_{1}\right)$ and kurtosis $\left(g_{2}\right)$

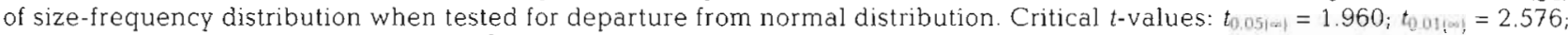
$t_{0.001 / \infty}=3.291$. S.d: S. droebachiensis; $\chi^{2}=\left(N_{\mathrm{r}}-1\right) \mathrm{V} / \mathrm{m}$ : chi-squared test, $H_{0}: \mathrm{V} / \mathrm{m}$ (variance/mean) ratio of population density $=1$;

$\hat{I}_{M}=\frac{V-m}{m^{2}-\left(V / N_{r}\right)}+1$ : Morisita's index; Significant test results indicated by asterisks: $p<0.05, \cdots p<0.01, \cdots p<0.001$

\begin{tabular}{|c|c|c|c|c|c|c|c|c|c|c|c|c|}
\hline \multirow[t]{2}{*}{ Site } & \multirow[t]{2}{*}{ Year } & \multicolumn{2}{|c|}{$\begin{array}{l}\text { Sample } \\
\text { size }\end{array}$} & \multirow{2}{*}{$\begin{array}{l}\text { Mean test } \\
\text { diameter } \\
(\mathrm{mm})\end{array}$} & \multicolumn{2}{|c|}{ Skewness } & \multicolumn{2}{|c|}{ Kurtosis } & \multicolumn{2}{|c|}{$\begin{array}{c}\text { Mean population } \\
\text { density }\end{array}$} & \multicolumn{2}{|c|}{ Aggregation } \\
\hline & & $\mathrm{N}$ & $N_{p}$ & & $g_{1}$ & $t_{\mathrm{s} 1}$ & $g_{2}$ & $t_{\mathrm{s} 2}$ & S.d. $\mathrm{m}^{-2}$ & $N_{r}$ & $x^{2}$ & $\hat{I}_{M}$ \\
\hline \multirow[t]{3}{*}{ Harbour Pier } & 1981 & 67 & & $38.8(1.68)$ & 0.099 & 0.338 & -0.936 & 1.668 & $47.8(10.4)$ & 17 & $153.5^{\cdots}$ & 1.755 \\
\hline & 1983 & 135 & 22 & $40.9(1.09)$ & -0.989 & $4.743 \cdots$ & 0.196 & 0.480 & $42.5(4.83)$ & 16 & 32.9 & 1.114 \\
\hline & 1992 & 148 & 13 & $35.9(1.39)$ & -0.292 & 1.465 & -1.278 & $3.270^{\circ}$ & $41.8(5.76)$ & 20 & $75.5^{\cdots}$ & 1.290 \\
\hline \multirow[t]{3}{*}{ Måstad } & 1981 & 41 & & $45.0(2.38)$ & -0.686 & 1.857 & -1.131 & 1.639 & $34.4(6.71)$ & 15 & $68.8^{\cdots}$ & 1.473 \\
\hline & 1983 & 223 & 47 & $37.6(1.02)$ & -0.511 & $3.136^{\circ}$ & -0.846 & $2.631^{\circ}$ & $55.3(7.41)$ & 16 & $59.7^{\cdots}$ & 1.220 \\
\hline & 1992 & 209 & 43 & $35.2(1.14)$ & -0.178 & 1.058 & -1.090 & $3.286^{\circ}$ & $75.0(10.68)$ & 19 & $130.1 \cdots$ & 1.339 \\
\hline \multirow[t]{3}{*}{ Lighthouse Bay } & 1981 & 526 & & $50.6(0.53)$ & -0.752 & $7.061 \cdots$ & -0.064 & 0.302 & & & & \\
\hline & 1983 & 105 & 44 & $41.1(1.69)$ & -0.103 & 0.437 & -1.356 & $2.958^{\circ}$ & $26.1(5.39)$ & 15 & $58.4^{\cdots}$ & 1.507 \\
\hline & 1992 & 342 & 74 & $30.3(0.97)$ & 0.402 & $3.048^{\circ}$ & -1.291 & $4.937^{\cdots}$ & $60.6(12.26)$ & 20 & $236.2 \cdots$ & 1.787 \\
\hline \multirow[t]{2}{*}{ Tiny Bay } & 1983 & 173 & 13 & $48.4(0.81)$ & -1.942 & $10.518^{\cdots} \cdot$ & 4.196 & $11.558 \cdots$ & $39.1(4.02)$ & 17 & $28.2^{\circ}$ & 1.079 \\
\hline & 1992 & 206 & 28 & $37.5(1.38)$ & -0.432 & $2.550^{\circ}$ & -1.44 & $4.311 \cdots$ & $45.1(14.43)$ & 15 & $242.6 \cdots$ & 2.615 \\
\hline
\end{tabular}

Table 2. Strongylocentrotus droebachiensis. Single factor analysis of the effect of sampling date on the density of 4 sea urchin populations at Værøy Island, Northern Norway. df: degrees of freedom; MS: mean square. Significant test results indicated by asterisks: ${ }^{\circ} p<0.05, \cdot p<0.01$

\begin{tabular}{|lrrc|}
\hline ANOVA & df & MS & F-value \\
\hline Harbour Pier (1981, 1983, 1992) & 2 & 186.720 & 0.196 \\
Residual & 50 & 950.925 & \\
Måstad (1981, 1983, 1992) & 2 & 6908.466 & $5.266 .$. \\
Residual & 47 & 1311.905 & \\
Lighthouse Bay (1983, 1992) & 1 & 10182.438 & $5.303^{\circ}$ \\
Residual & 33 & 1920.137 & \\
Tiny Bay (1983, 1992) & 1 & 287.625 & 0.179 \\
Residual & 30 & 1604.262 & \\
& & & \\
Tukey-Kramer & df & Difference & Critical \\
post hoc comparison & & & value \\
\hline Måstad 1981 vs Måstad 1983 & 29 & 20.850 & 31.534 \\
Mastad 1981 vs Måstad 1992 & 32 & 40.547 & $38.375 .$. \\
Måstad 1983 vs Måstad 1992 & 33 & 19.697 & 29.772 \\
\hline
\end{tabular}

\section{Parasite prevalence}

The maximum prevalence of Echinomermella matsi at Værøy Island decreased from $\sim 40 \%$ in 1983 to $-20 \%$ in 1992. This reduction, which occurred at the Lighthouse Bay site, was the only significant change in parasite prevalence (Table 3). However, parasite prevalence underwent a near significant reduction from 16.3 to $8.8 \%$ at the Harbour Pier site, and a near significant increase from 7.5 to $14 \%$ in Tiny Bay (Table 3 ). At Måstad parasite prevalence remained virtually un-

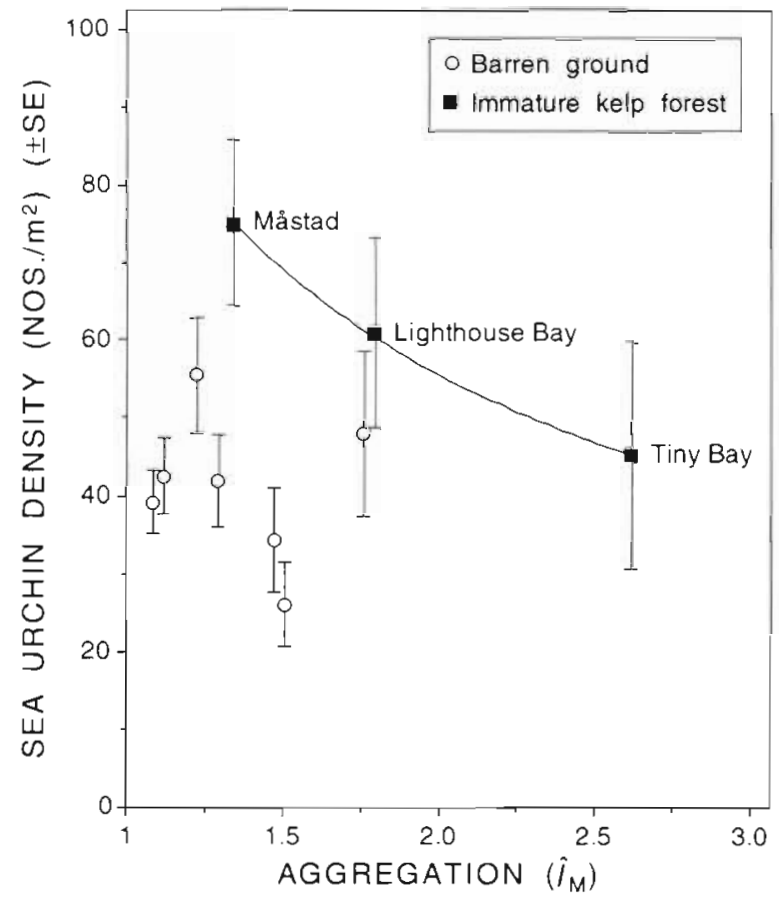

Fig. 3. Strongylocentrotus droebachiensis. Population density and degree of aggregation in sea urchin samples from Værøy Island, Northern Norway. Three data points connected by a power curve represent samples from the successionally immature kelp forest. These samples were taken in 1992, at the time of the onset of recurrent destructive grazing. $\hat{l}_{M}$ : Morisita's index

changed at approximately $20 \%$. These results suggest that the prevalence of E. matsi at Værøy Island is now at an intermediate level. 
Table 3. Strongyiocentrotus droebachiensis and Echinomermella matsi. Analysis of changes in parasite prevalence in sea urchin populations at Værøy Island, Northern Norway. G-test of the null hypothesis: parasite prevalence is independent of sampling date (1983 or 1992). Critical values for $G: \chi_{0.05(1)}^{2}=3.841$ and $\chi_{0.001(1)}^{2}=10.828$. Significant test results indicated by asterisks: ${ }^{*} p \approx 0.05, \cdots p<0.001$

\begin{tabular}{|c|c|c|c|c|c|}
\hline Site & Year & $\begin{array}{c}\text { Prevalence } \\
(\%)\end{array}$ & $\begin{array}{r}\Delta \text { Preva } \\
\text { Difference }\end{array}$ & $\begin{array}{l}\text { alence } \\
\% \text { Change }\end{array}$ & $G$-value \\
\hline Harbour Pier & $\begin{array}{l}1983 \\
1992\end{array}$ & $\begin{array}{r}16.3 \\
8.8\end{array}$ & -7.5 & -46.1 & $3.697^{1 \cdot 1}$ \\
\hline Måstad & $\begin{array}{l}1983 \\
1992\end{array}$ & $\begin{array}{l}21.1 \\
20.6\end{array}$ & -0.5 & -2.4 & 0.016 \\
\hline Lighthouse Bay & $\begin{array}{l}1983 \\
1992\end{array}$ & $\begin{array}{l}41.9 \\
21.6\end{array}$ & -20.3 & -48.4 & $15.964 \cdots$ \\
\hline Tiny Bay & $\begin{array}{l}1983 \\
1992\end{array}$ & $\begin{array}{r}7.5 \\
13.6\end{array}$ & 6.1 & 80.9 & $3.699^{(\bullet)}$ \\
\hline
\end{tabular}

\section{Test diameter and size-frequency distribution}

Six out of 8 possible tests suggested that sea urchins at Værøy Island were smaller in 1992 than they were in 1983 (Table 4, Fig. 4); only non-infected urchins from Måstad and infected urchins from the Harbour Pier site had similar mean test diameters. This is an indication. of increased abundance of juvenile sea urchins, since sea urchin densities in 1992 were similar or higher than in 1983 (Tables 1 \& 2).

Infected sea urchins from the re-established kelp forest (Måstad 1992, Lighthouse Bay 1992, Tiny Bay 1992) were significantly smaller than non-infected urchins, whereas no significant size differences were detected between infected and non-infected urchins from the barren grounds (Table 4, Fig. 4).

In 1992 the peakedness of the size-frequency distribution of Stongylocentrotus droebachiensis had changed from normal or leptokurtic, to significantly platykurtic, at all 4 sites (Table 1, Fig. 5), i.e. the relative abundance of juvenile sea urchins had increased. Increased juvenile abundance is also indicated by significant rightward changes in the skewness of the size-frequency distributions at 3 sites and a drop in significance level at 1 site (Tiny Bay) (Table 1; Fig. 5). The absolute abundance of adults had evidently decreased at sites where sea urchin density appeared unchanged (Harbour Pier, Tiny Bay), but juvenile abundance must have increased at sites with higher density (Måstad, Lighthouse Bay, Table 1). How- ever, as mentioned above, it has been observed (Harbour Pier, Lighthouse Bay), or can be inferred from the history of kelp forest recovery (Måstad, Tiny Bay), that adult sea urchin density at all sites must have been considerably lower at some point in the 1984 to 1991 time interval than it was in either 1983 or 1992.

The shape of the size-frequency distributions indicates that recent recruitment has been good (Fig. 5). Furthermore, the presence of urchins $\geq 60 \mathrm{~mm}$ in test diameter in all samples from 1992 indicate that there has been a continuous presence of sea urchins at all field sites during the period of kelp recovery (Fig. 5).

\section{DISCUSSION}

\section{Macroalgae recovery}

The first localized regrowth of the macroalgal vegetation in Northern Norway was observed in 1984 at Værøy Island (Hagen 1987), only 3 to 4 yr after the original kelp forest in this area had been eliminated by outbreak populations of Strongylocentrotus droebachiensis (Hagen 1983). By 1992, most of the urchin-domi-

Table 4. Strongylocentrotus droebachiensis and Echinomermella matsi Analysis of the effects of parasite status and sampling date on the test diameter of sea urchins from Værøy Island, Northern Norway. Significant test results indicated by asterisks: ${ }^{(\cdot)} p \approx 0.05, " p<0.05, \cdots p<0.01, \cdots p<0.001$

\begin{tabular}{|lcc|}
\hline Kolmogorov-Smirnov & Test statistic & p-value \\
\hline Harbour Pier & & \\
1983 infected vs 1983 non-infected & 3.173 & 0.4092 \\
1983 infected vs 1992 infected & 2.014 & 0.7305 \\
1983 non-infected vs 1992 non-infected & 11.113 & $0.0077 \cdots$ \\
1992 infected vs 1992 non-infected & 1.131 & $>0.9999$ \\
Måstad & & \\
1983 infected vs 1983 non-infected & 6.840 & 0.0654 \\
1983 infected vs 1992 infected & 28.356 & $<0.0001 \cdots$ \\
1983 non-infected vs 1992 non-infected & 1.764 & 0.8277 \\
1992 infected vs 1992 non-infected & 17.039 & $0.0004 \cdots$ \\
Lighthouse Bay & & \\
1.983 infected vs 1983 non-infected & 7.297 & $0.0521^{\prime \cdot 1}$ \\
1983 infected vs 1992 infected & 52.893 & $<0.0001 \cdots$ \\
1983 non-infected vs 1992 non-infected & 7.350 & $0.0507 \cdot \cdots$ \\
1992 infected vs 1992 non-infected & 34.031 & $<0.0001 \cdots$ \\
Tiny Bay & & \\
1983 infected vs 1983 non-infected & 3.182 & 0.4075 \\
1983 infected vs 1992 infected & 11.596 & $0.0061 \cdots$ \\
1983 non-infected vs 1992 non-infected & 32.545 & $<0.0001 \cdots$ \\
1992 infected vs 1992 non-infected & 8.557 & 0.0277 \\
\hline
\end{tabular}


nated barren grounds at Værøy Island had reverted to dense kelp forest, and age determination of the perennial Laminaria hyperborea plants, which can be $>15$ yr old (Kain 1967, Sjøtun et a1. 1993), indicated that widespread kelp regrowth had occurred as early as 1986 to 1987.

The new kelp forest at Varøy Island, although 4 to $7 \mathrm{yr}$ old, was still lacking the characteristic undergrowth and epiphyte assemblages of the original kelp forest (Hagen 1983, Fig. 5 therein, Hagen 1987, Fig. 7 therein). Previous studies in established kelp forests suggest that the rugose stipes of Laminaria hyperborea are colonized in a nonlinear fashion, whereby the biomass of the attached flora and fauna increases abruptly when the kelp plants are approximately 5 yr old (Whittick 1983, Høisæter et al. 1992, Rinde et al. 1992, Høisæter \& Ødegaard 1994). However, the colonization of the stipes in the new kelp forest at Værøy Island appeared to be delayed, perhaps because propagules of the previously associated organisms were scarce due to the virtual absence of established kelp forest in the vicinity of the island.

Signs of site-specific macrophyte recovery elsewhere in Northern Norway (Skadsheim et al. 1994) suggest that the observed macrophyte recovery at Værøy Island is but a local manifestation of a process operating on a larger geographic scale. This gradual and spatially variable transition, from urchin barren grounds to kelp forest, differs from the rapid kelp recolonization which followed when a decade of sea urchin dominance was terminated by mass mortalities of Strongylocentrotus droebachiensis off Nova Scotia in the early 1980s (Scheibling \& Stephenson 1984, Miller 1985b, Novaczek \& McLachlan 1986, Scheibling 1986, Johnson \& Mann 1988). The swiftness of the Nova Scotian kelp recovery was apparently a result of complete sea urchin population die-offs along sections of the Atlantic coast of the province (Scheibling 1986) In contrast, the analyses of sea urchin size frequencies and kelp age at Værøy Island suggest that kelp recovery has been impeded by the continued presence of diminishing sea urchin populations.

\section{Recurrent destructive grazing}

In 1992, destructive grazing of the successionally immature re-established kelp forest at Værøy Island was nearly complete at 1 field site, initiated at another, and appeared imminent at the 2 remaining sites. One year later, in August 1993, the barren ground site appeared qualitatively unchanged, but there was evidence of destructive grazing at the macrophyte sites. Canopy cover reductions ranged from $\sim 10$ to $>50 \%$, and the spatial extent of the kelp forest destruction was proportional to the mean density of the resident urchin population. These results suggest that the new kelp forest is being eliminated before it reaches the $\sim 10$ to 20 yr persistence a Laminaria hyperborea forest requires to attain ecological maturity (cf. Høisæter \& Ødegaard 1994)

The spatial progression of destructive grazing in the re-established kelp forest at Værøy Island followed a site-specific pattern, similar to that of the original kelp forest destruction (Hagen 1983). However, the actual grazing process differed in that there was virtually no undergrowth or epiphyte assemblages for the urchins to graze before the new kelp plants were attacked.

The onset of destructive grazing is governed by the local abundance and feeding behaviour of the sea urchins, i.e. the urchins switch from a passive detritivorous mode of feeding to an active herbivorous mode of feeding when their local abundance has increased beyond a critical threshold value (Mann 1977. Harrold \& Reed 1985, Harrold \& Pearse 1987). The critical local abundance threshold of Strongylocentrotus droebachiensis in a Nova Scotian Laminaria 


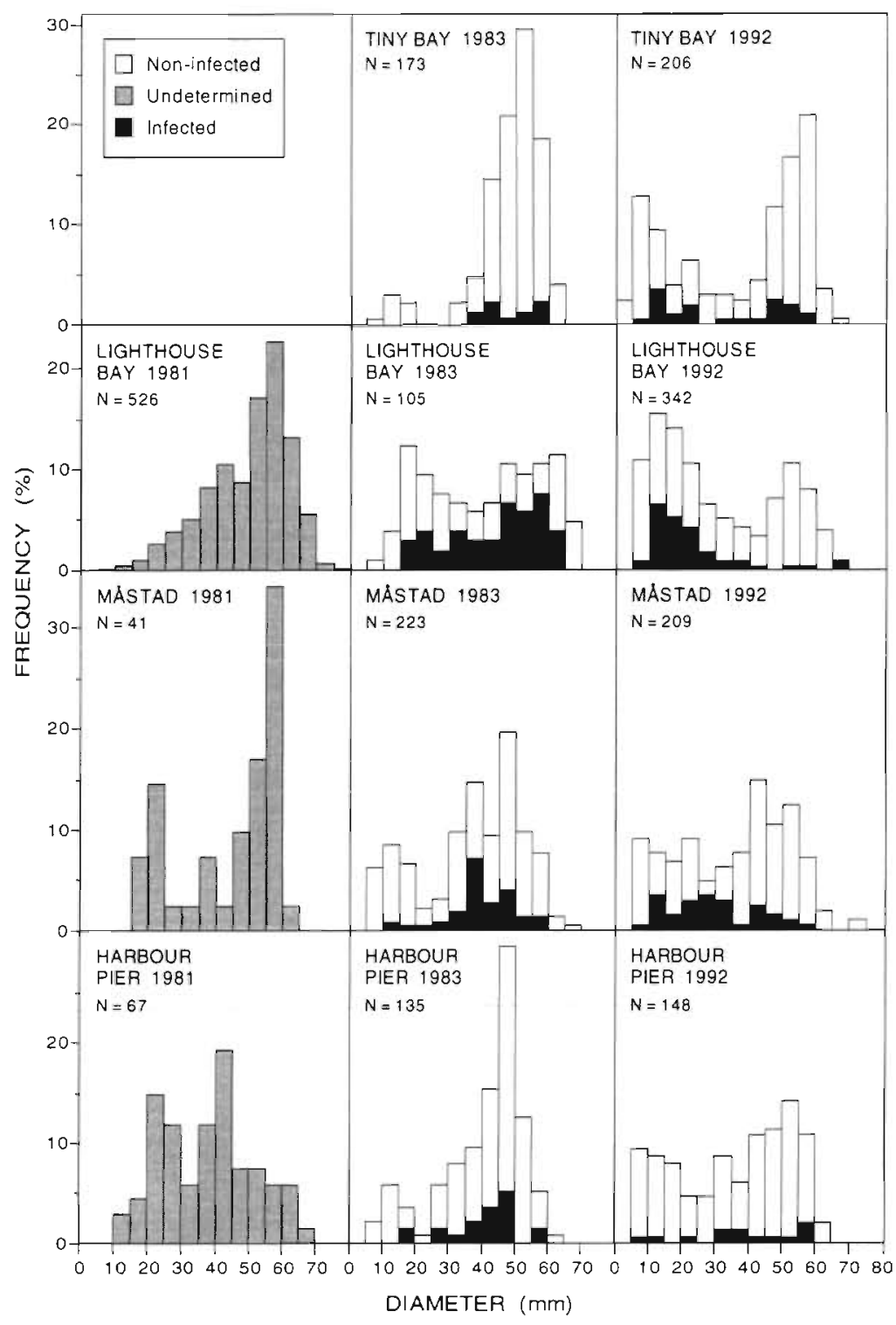

Fig. 5. Strongylocentrotus droebachiensis and Echinomermella matsi. Sizefrequency distributions of infected and non-infected sea urchins in samples from Værøy Island, Northern Norway

mates from the 3 kelp forest sites at Værøy Island, is apparently the first explicit estimate of these threshold conditions for any kelp forest system (Fig. 3). The curve specifies a testable hypothesis and provides a quantitative predictor of impending destructive grazing.

The degree of aggregation in the kelp resident urchin populations at Værøy Island was inversely related to population density, i.e. the highest level of aggregation occurred at the lowest population density. This result is contrary to results from laboratory experiments which indicate that Strongylocentrotus droebachiensis becomes increasingly aggregated in response to increasing density (Hagen \& Mann 1994). However, both field observations (Bernstein et al. 1981) and laboratory experiments (Hagen \& Mann 1994) suggests that the presence of wolffish, Anarhichas lupus L., makes sea urchins less aggregated. The wolffish is common in the study area. It is a visual predator (Keats et al. 1986), which increases its consumption of sea urchins in response to increasing sea urchin density (Hagen \& Mann 1992). It is possible, therefore, that increasing density may have made the sea urchin populations more attractive to foraging wolffish. It is also possible that lower levels of aggregation in barren grounds (Fig. 3) may be related to an increased presence of wolffish.

The observed recurrence of destructive grazing by Strongylocentrotus droebachiensis at Værøy Island is apparently unprecedented for Norwegian waters. There is only von Düben's (1847) $150 \mathrm{yr}$ old report of kelp forest destruction prior to the current sea urchin outbreak. This is

longicruris forest was estimated at ca $2 \mathrm{~kg}$ urchin biomass $\mathrm{m}^{-2}$ (Breen \& Mann 1976). However, the local abundance or density of a population is rarely equal to its mean value but may vary depending on the population's degree of aggregation (Pielou 1977. Hurlbert 1990). Therefore, the estimation of a local density threshold for the onset of destructive grazing in a kelp forest requires an estimate of the sea. urchin population's degree of aggregation in addition to an estimate of its mean density. In general, the threshold conditions will include a range of mutually dependent density and aggregation values. The curve in the aggregation-density plane, which connects estidifferent from the situation in the Northwest Atlantic where there is 1 historical report of kelp bed destruction by $S$. droebachiensis (Scott 1902), several anecdotal references to past sea urchin outbreaks (Stephens 1972, Adey \& Macintyre 1973, Breen 1980, Wharton \& Mann 1981, Pringle et al. 1982, Miller 1985a) or high densities of $S$. droebachiensis (Stimpson 1854, Verrill 1866, Ganong 1885, Dexter 1944, Swan 1966), 1 welldocumented outbreak (Breen \& Mann 1976, Wharton \& Mann 1981, Miller \& Colodey 1983, Scheibling \& Stephenson 1984, Miller 1985b, Scheibling 1986), and most recently a suggestion that yet another outbreak is underway (Scheibling et al. 1994). 


\section{Dynamics of outbreak termination}

The rocky subtidal habitat at Værøy Island has gone from undisturbed Laminaria hyperborea forest, to Strongylocentrotus droebachiensis-dominated barren ground, to immature kelp forest, and back to barren ground again in little more than $10 \mathrm{yr}$ (Figs. 2 \& 6). The observed kelp forest recovery was predicted by the macroparasite hypothesis which states that epizootic occurrence of the endoparasitic nematode Echinomermella matsi may terminate sea urchin outbreaks in Northern Norway by reducing the density of adult sea urchins sufficiently to permit recovery of macroalgae (Hagen 1987, Hagen 1992).

Density reduction caused by parasite-related host mortality is expected to alter the size-frequency distribution of the sea urchins, from an unimodal shape with a peak in the larger size classes, to a bimodal shape or

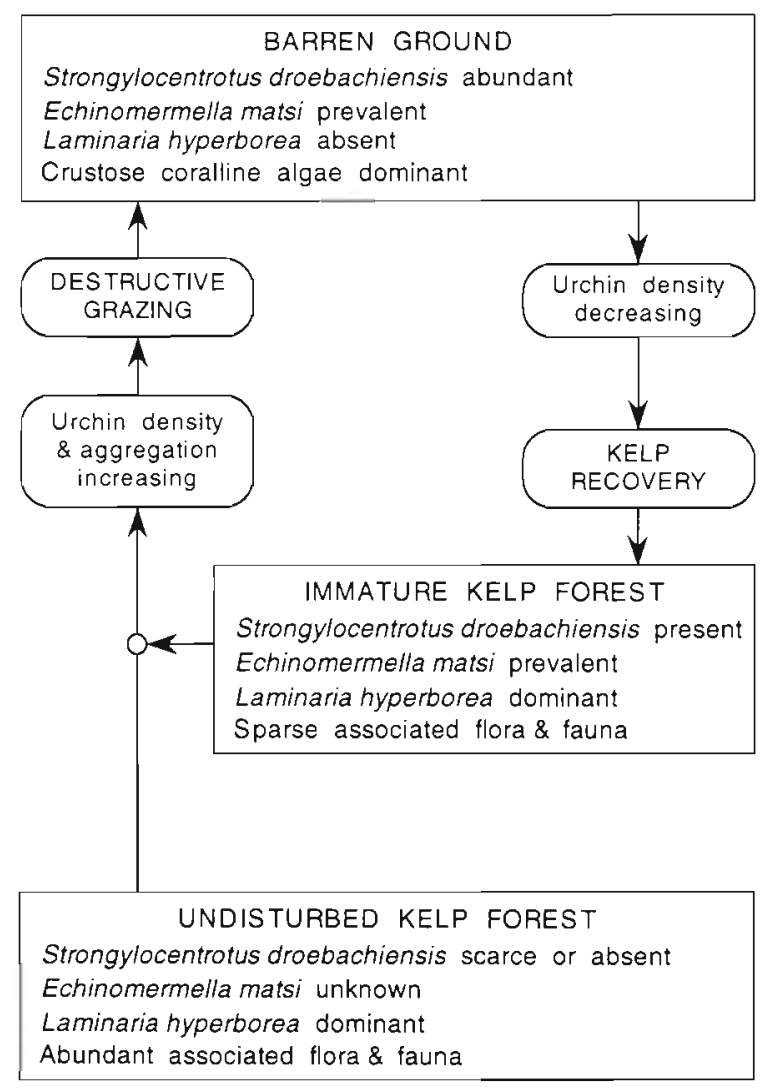

Fig. 6. Strongylocentrotus droebachiensis, Echinomermella matsi and Laminaria hyperborea. Scenario based on observed sea urchin outbreak dynamics at Værøy Island, Northern Norway: a barren ground configuration is established after the initial destruction of the undisturbed kelp forest. Subsequent kelp recovery is followed by recurrent destructive grazing which prematurely interrupts the succession towards a mature, undisturbed kelp forest, and the ecosystem enters a cyclical domain which precludes proper termination of the outbreak an unimodal shape with a peak in the smaller size classes (Hagen 1992). The observed changes in the size-frequency distributions of Strongylocentrotus droebachiensis from Værøy Island are consistent with this prediction. Parasite-related host mortality is also expected to prevent accumulation of infected individuals in the larger size classes. Again, the results are consistent with this prediction, as the mean test diameter of infected sea urchins in the kelp forest was smaller than, and in the barren ground equal to, the mean test diameter of non-infected sea urchins. This may, furthermore, be an indication that the susceptibility of small urchins to infection by Echinomermella matsi is independent of the prevailing community configuration, whereas, large, presumably well-nourished urchins in the kelp forest are less susceptible than their starved counterparts in the barren grounds.

Whether the observed kelp forest recovery at Værøy Island was actually induced by Echinomermella matsi is still a matter of debate, as it has been suggested that hitherto unknown sources of adult sea urchin mortality may be operating independently or in conjunction with E. matsi (Stien 1993, Skadsheim et al. 1994). Nevertheless, the succession towards an ecologically mature kelp forest community has been interrupted by the unexpected recurrence of destructive grazing, and the macroparasite hypothesis must therefore be rejected in its present form. It is also evident that the basic dichotomy between barren ground and kelp forest, which has been used as a descriptive metaphor for outbreaks of Strongylocentrotus droebachiensis in the Northwest Atlantic (e.g. Chapman \& Johnson 1990), does not exhaust the dynamic possibilities of the interaction between macrophytes and sea urchins in Northern Norway.

The possibility of cyclical sea urchin-mediated changes in community structure has been discussed by earlier authors (Mann 1977, Scheibling 1984), but all previously known transitions between barren ground and kelp forest have been irregular occurrences without any detectable periodicity (reviews by Harrold \& Pearse 1987, Chapman \& Johnson 1990). The situation in Northern Norway differs by providing a macroparasitic disease agent as a theoretically plausible mechanism for sustaining future alternations (cf. May \& Anderson 1979, May 1983). A tentative etimate for the period of future alternations is provided by the approximately decade long interval from the initial kelp forest destruction until the recurrence of destructive grazing.

Local events at Værøy Island are part of a large-scale outbreak phenomenon which started in the late 1970 s and involves much of the Norwegian coastline between 64 and $69^{\circ} \mathrm{N}$ (Sivertsen 1982, Hagen 1983). Signs of local scale macroalgae recovery elsewhere in 
the outbreak area (Skadsheim et al. 1994) may therefore mark the beginning of new waves of kelp forest destruction, rather than marking the end of the outbreak. On a larger scale these events may be an indication that the euphotic hard-bottom component of the coastal ecosystem has entered a cyclical domain where barren ground alternates with immature kelp forest in a hitherto unrecognized manner.

Acknowledgements. I thank O. A. Schistad for SCUBA diving assistance, P. Torrissen for the safe operation of RV 'Raud', and $\mathrm{H}$. H. Ludvigsen for assistance in the laboratory. Thanks also go to H. K. Marshall for improving the linguistic content of the manuscript, to G. M. Jones and J. M. Watanabe for commenting on an earlier draft, and to 3 anonymous referees for valuable criticism. My employer, Bodø College, Norway, generously provided technical assistance and laboratory facilities, and the National Research Institute of Aquaculture, Japan provided time for manuscript preparation.

\section{LITERATURE CITED}

Adey WH, Macintyre IG (1973) Crustose coralline algae: a reevaluation in the geological sciences. Geol Soc Am Bull $84: 883-904$

Anderson RM, May RM (1979) Population biology of infectious diseases: Part I. Nature 280:361-367

Andrew NL (1991) Changes in subtidal habitat following mass mortality of sea urchins in Botany Bay, New South Wales. Aust $\mathrm{J}$ Ecol 16:353-362

Andrew NL, Choat JH (1982) The influence of predation and conspecific adults on the abundance of juvenile Evechinus chloroticus (Echinoidea: Echinodermata). Oecologia 54 $80-87$

Bennington CC, Thayne WV (1994) Use and misuse of mixed model analysis of variance in ecological studies. Ecology 75\{3\}:717-722

Bernstein BB, Williams BE, Mann KH (1981) The role of behavioral responses to predators in modifying urchins' (Strongylocentrotus droebachiensis) destructive grazing and seasonal foraging patterns. Mar Biol 63:39-49

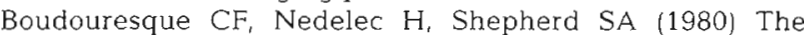
decline of a population of the sea urchin Paracentrotus lividus in the Bay of Port-Cros (Var, France). Trav Sci Parc Nation Port-Cros 6:243-251

Breen PA (1980) Relations among lobster, sea urchins, and kelp in Nova Scotia. In: Pringle JD, Sharp GJ, Caddy JF (eds) Proceedings of the workshop on the relationship between sea urchin grazing and commercial plant/animal harvesting. Can Tech Rep Fish Aquat Sci 954:24-32

Breen PA, Carson TA, Foster JB, Stewart A (1982) Changes in subtidal community structure associated with British Columbia sea otter transplants. Mar Ecol Prog Ser 7:13-20

Breen PA, Mann KH (1976) Destructive grazing of kelp by sea urchins in eastern Canada. J Fish Res Bd Can 33:1278-1283

Chapman ARO (1981) Stability of sea urchin dominated barren grounds following destructive grazing of kelps in St. Margaret's Bay, eastern Canada. Mar Biol 62:307-311

Chapman ARO, Johnson CR (1990) Disturbance and organization of macroalgal assemblages in the Northwest Atlantic. Hydrobiologia 192:77-121

Dayton PK (1985) Ecology of kelp communities. A Rev Ecol Syst 16:215-245
Dayton PK, Currie V, Gerrodette T, Keller BD, Rosenthal R, Tresca DV (1984) Patch dynamics and stability of some Californa kelp communities. Ecol Monogr 54:253-289

Dayton PK, Tegner MJ, Parnell PE, Edwards PB (1992) Temporal and spatial patterns of disturbance and recovery in a kelp forest community. Ecol Monogr 62(3):421-445

Dexter RW (1944) The bottom community at Ipswich Bay, Massachusetts. Ecology 25:352-359

Düben v (1847) Om de norske Echinider. In: Anonymous (ed) Forhandlinger ved de skandinaviske naturforskeres fjerde möde i Christiania den 11-18 Juli 1844. Gröndahl, Christiania, p 250-255 (in Norwegian)

Duggins DO (1980) Kelp beds and sea otters: an experimental approach. Ecology 61:447-453

Duggins DO (1981) Sea urchins and kelp: the effects of short term changes in urchin diet. Limnol Oceanogr 26 : 391-394

Ebeling AW, Laur DR, Rowley RJ (1985) Severe storm disturbances and reversal of community structure in a southern California kelp forest. Mar Biol 84:287-294

Elliott JM (1977) Some methods for the statistical analysis of samples of benthic invertebrates. Freshwat biol Ass Sci Publ 25:1-160

Estes JA, Harrold C (1988) Sea otters, sea urchins, and kelp beds: some questions of scale. In: VanBlaricom GR, Estes JA (eds) The community ecology of sea otters. SpringerVerlag, Berlin, p 116-150

Estes JA, Palmisano JF (1974) Sea otters: their role in structuring nearshore communities. Science 185:1058-1060

Foreman RE (1977) Benthic community modification and recovery following intensive grazing by Strongylocentrotus droebachuensis. Helgoländer wiss Meeresunters 30:468-484

Foster MS, Schiel DR (1988) Kelp communities and sea otters: keystone species or just another brick in the wall? In: VanBlaricom GR, Estes JA (eds) The community ecology of sea otters. Springer-Verlag, Berlin, p 92-115

Gagnon J, Haycock KA, Roth JM, Plamondon J, Carrol M, Simpson J (1989) SuperANOVA. Accessible linear modelling. Abacus Concepts, Inc, Berkeley, CA

Ganong WF (1885) On the zoology of the invertebrate animals of Passamaquoddy Bay. Bull Natl Hist Soc, New Brunswick 1:87-97

Hagen NT (1983) Destructive grazing of kelp beds by sea urchins in Vestfjorden, northern Norway. Sarsia 68:177-190

Hagen NT (1987) Sea urchin outbreaks and nematode epizootics in Vestfjorden, northern Norway. Sarsia 72:213-229

Hagen NT (1992) Macroparasitic epizootic disease: a potential mechanism for the termination of sea urchin outbreaks in Northern Norway. Mar Biol 114:469-478

Hagen NT, Mann KH (1992) Functional response of the predators American lobster Homarus americanus (MilneEdwards) and Atlantic wolffish Anarhichas lupus (L.) to increasing numbers of the green sea urchin Strongylocentrotus droebachiensis (Müller). J exp mar Biol Ecol 159: $89-112$

Hagen NT, Mann KH (1994) Experimental analysis of factors influencing the aggregating behaviour of the green sea urchin Strongylocentrotus droebachiensis (Müller). J exp mar Biol Ecol 176:107-126

Harris LG, Ebeling AW, Laur DR, Rowley RJ (1984) Community recovery after storm damage: a case of facilitation in primary succession. Science 224:1336-1338

Harrold C, Pearse JS (1987) The ecological role of echinoderms in kelp forests. Echinoderm Stud 2:137-233

Harrold C, Reed D (1985) Food availability, sea urchun grazing, and kelp forest community structure. Ecology 66: $1160-1169$ 
Himmelman JH, Cardinal A, Bourget E (1983) Community development following removal of urchins, Strongylocentrotus droebachiensis, from the rocky subtidal zone in the St. Lawrence Estuary, eastern Canada. Oecologia 59: $27-39$

Høisæter T, Lein TE, Fosså JH (1992) Tareskogen som habitat og oppvekstområde for fisk i relasjon til eventuelle skadevirkninger av taretråling. Et forprosjekt (IFM Rap No 3.1992). Dept Fish Mar Biol, Univ Bergen (in Norwegian)

Hoisæter T, Odegaard S (1994) Tareskogens betydning for kystnæere fiskebestander - del Il (IFM Rapport No 8.1994). Dept Fish Mar Biol, Univ Bergen (In Norwegian)

Hughes TP, Reed DC, Boyle MJ (1987) Herbivory on coral reefs: community structure following mass mortalities of sea urchins. J exp mar Biol Ecol 113(1):39-59

Hurlbert SH (1990) Spatial distribution of the montane unicorn. Oikos 58:257-271

Johnson CR, Mann KH (1988) Diversity, patterns of adaptation, and stability of Nova Scotian kelp beds. Ecol Monogr $58(2): 129-154$

Jones GM (1985) Paramoeba invadens n. sp. (Amoebida, Paramoebidae), a pathogenic amoeba from the sea urchin, Strongylocentrotus droebachiensis, in eastern Canada. J Protozool 32:564-569

Jones GM, Hagen NT (1987) Echinomermella matsi sp. n., an endoparasitic nematode from the sea urchin Strongylocentrotus droebachiensis in northern Norway. Sarsia 72:203-212

Jones GM, Hebda AJ, Scheibling RE, Miller RE (1985a) Amoebae in tissues of diseased echinoids (Strongylocentrotus droebachiensis) in Nova Scotia. In: Keegan BF. O'Connor BDS (eds) Echinodermata. Proc 5th Int Echinoderm Conf Galway. Balkema, Rotterdam, p 289-293

Jones GM, Hebda AJ, Scheibling RE, Miller RE (1985b) Histopathology of the disease causing mass mortality of sea urchins (Strongylocentrotus droebachiensis) in Nova Scotia. J Invertebr Pathol 45:260-271

Jones GM, Scheibling RE (1985) Paramoeba sp. (Amoebida, Paramoebidae) as the possible causative agent of sea urchin mass mortality in Nova Scotia. J Parasitol 71: $559-565$

Kain JM (1963) Aspects of the biology of Laminaria hyperborea. II. Age, weight and length. J mar biol Ass UK 43: $129-151$

Kain JM (1967) Populations of Laminaria hyperborea at various latitudes. Helgoländer wiss Meeresunters 15:489-499

Keats D, South GR, Steele DH (1990) Effects of an experimental reduction in grazing by green sea urchins on a benthic macroalgal community in eastern Newfoundland. Mar Ecol Prog Ser 68:181-193

Keats D, Steele DH, South GR (1986) Atlantic wolffish (Anarhichas lupus L.; Pisces: Anarchichidae) predation on green sea urchins (Strongylocentrotus droebachiensis (O.F. Mull.); Echinodermata: Echinoidea) in eastern Newfoundland. Can J Zool 64:1920-1925

Lawrence JM (1975) On the relationships between marine plants and sea urchins. Oceanogr mar biol A Rev 13: $213-286$

Lawrence JM, Sammarco PW (1982) Effects of feeding on the environment: Echinoidea. In: Jangoux M, Lawrence JM (eds) Echinoderm nutrition. AA Balkema, Rotterdam, p $499-519$

Leighton DL (1971) Grazing activities of benthic invertebrates in southern California kelp beds. Nova Hedwigia (Beih) $32: 421-453$

Leighton DL, Jones LG, North WJ (1966) Ecological relationships between giant kelp and sea urchins in southern California. In: Young EG, McLachlan J (eds) Proc 5th int
Seaweed Symp, Halifax, August 25-28, 1965. Pergamon Press, Inc, Oxford, p 141-153

Lessios HA, Robertson DR, Cubit JD (1984) Spread of Diadema mass mortality through the Caribbean. Science 226:335-337

Mann KH (1977) Destruction of kelp-beds by sea-urchins: a cyclical phenomenon or irreversible degradation? Helgoländer wiss Meeresunters 30:455-467

May RM (1983) Parasitic infections as regulators of animal populations. Am Sci 71:36-45

May RM, Anderson RM (1979) Population biology of infectious diseases: Part II. Nature 280:455-461

Miller RJ (1985a) Seaweeds, sea urchins, and lobsters: a reappraisal. Can J Fish Aquat Sci 42:2061-2072

Miller RJ (1985b) Succession in sea urchin and seaweed abundance in Nova Scotia, Canada. Mar Biol 84:275-286

Miller RJ, Colodey AG (1983) Widespread mass mortalities of the green sea urchin in Nova Scotia, Canada. Mar Biol $73: 263-267$

Morisita M (1971) Composition of the I-index. Res Popul Ecol 13:1-27

Novaczek I, McLachlan J (1986) Recolonization by algae of the sublittoral habitat of Halifax County, Nova Scotia. following the demise of sea urchins. Bot mar 29:69-73

Pearse JS, Costa DP, Yellin MB, Agegian CR (1977) Localized mass mortality of red sea urchin, Strongylocentrotus franciscanus, near Santa Cruz, California. Fish Bull US $53: 645-648$

Pearse JS, Hines AH (1979) Expansion of a central California kelp forest following the mass mortality of sea urchins Mar Biol 51:83-91

Pielou EC (1977) Mathematical ecology. Wiley \& Sons, New York

Pringle JD, Sharp GJ, Caddy JF (1982) Interactions in kelp bed ecosystems in the Northwest Atlantic: review of a workshop. In: Mercer MC (ed) Multispecies approaches to fisheries management advice. Can Spec Publ Fish Aquat Sci 59:108-115

Rinde E, Christie H, Fredriksen S, Sivertsen A (1992) Ecological consequences of kelp trawling: importance of the structure of the kelp forest for abundance of fauna in the kelp holdfasts, benthic fauna and epiphytes (Oppdragsrapport No 127:1-37). NINA, Oslo, p 1-37 (in Norwegian with English abstract)

Sager S, Rocco T, Spector P, Bauer L (1992) StatView. Abacus Concepts, Inc, Berkeley, CA

Scheibling RE (1984) Echinoids, epizootics and ecological stability in the rocky subtidal off Nova Scotia, Canada. Helgoländer Meeresunters 37:233-242

Scheibling RE (1986) Increased macroalgal abundance following mass mortalities of sea urchins (Strongylocentrotus droebachiensis) along the Atlantic coast of Nova Scotia. Oecologia 68:186-198

Scheibling RE, Henniger AW, Balch T (1994) The dynamics of destructive grazing of kelp beds by sea urchins in Nova Scotia. In: David B, Guille A, Féral JP, Roux M (eds) Echinoderms through time. Proc 8th International Echinoderm Conference, September 6-10, 1993. Université de Bourgogne, Dijon

Scheibling RE, Stephenson RL (1984) Mass mortality of Strongylocentrotus droebachiensis (Echinodermata: Echinoidea) off Nova Scotia, Canada. Mar Biol 78:153-164

Schiel DR, Foster MS (1986) The structure of subtidal algal stands in temperate waters. Oceanogr mar biol A Rev 24:265-307

Scott FH (1902) Food of the sea-urchin (Strongylocentrotus dröbachiensis). Contr Can Biol 1901-2:49-54 
Sivertsen K (1982) Utbredelse og variasjon + kråkebollenes nedbeiting av tareskogen på vestkysten av Norge No 7/82. Nordlandsforskning (Nordland Research Institute), Bodö (in Norwegian)

Sjøtun K, Fredriksen S, Lein TE, Rueness J, Sivertsen K (1993) Population studies of Laminaria hyperborea from its northern range of distribution in Norway. Hydrobiologia 260/261:215-221

Skadsheim A, Rinde $E_{1}$ Christie $H$ (1994) Occurrence and changes in sea urchin density, sea urchin parasite and regrowth of kelp forest along the Norwegian coast from Trøndelag to Troms (Oppdragsrapport No 258). NINA, Oslo (in Norwegian with English Summary)

Sokal RR, Rohlf FJ (1981) Biometry. The principles and practice of statistics in biological research, 2 nd edn. WH Freeman, San Francisco

Stephens RE (1972) Studies on the development of the sea urchin Strongylocentrotus droebachiensis. I. Ecology and normal development. Biol Bull 142:132-144

Stien A (1993) The ecology and epidemiology of Echinomermella matsi (Nematoda), a parasite of the sea urchin Strongylocentrotus droebachiensis. Cand Scient thesis, University of Oslo

This article was submitted to the editor
Stimpson W (1854) Synopsis of the manne invertebrata of Grand Manan: or the region about the mouth of the Bay of Fundy, New Brunswick. Smithsonian Contr mar Sci 6 : $1-67$

Swan EF (1966) Growth, autotomy, and regeneration. In Boolootian RA (ed) Physiology of Echinodermata. Wiley \& Sons, New York, p 397-434

Verrill AE (1866) On the polyps and echinoderms of New England, with descriptions of new species. Proc Boston Soc Nat Hist 10:333-357

Watanabe JM, Harrold C (1991) Destructive grazing by sea urchins Strongylocentrotus spp. in a central California kelp forest: potential roles of recruitment, depth, and predation. Mar Ecol Prog Ser 71:125-141

Wharton WG, Mann KH (1981) Relationship between destructive grazing by the sea urchin, Strongylocentrotus droebachiensis, and the abundance of American lobster. Homarus americanus, on the Atlantic coast of Nova Scotia Can J Fish Aquat Sci 38:1339-1349

Whittick A (1983) Spatial and temporal distributions of dominant epiphytes on the stipes of Laminaria hyperborea (Gunn.) Fosl. (Phaeophyta: Laminariales) in S.E. Scotland. J exp mar Biol Ecol 73:1-10

Manuscript first received: October 11, 1994

Revised version accepted: February 21, 1995 